\title{
Does seed treatment affect wheat yield components?
}

\author{
Joice Aline Freiberg ${ }^{1 *}$, Marcos Paulo Ludwig ${ }^{2}$, Eduardo Girotto ${ }^{3}$
}

DOI: https://doi.org/10.35699/2447-6218.2021.29642

\begin{abstract}
A variety of products have been used on seeds to maintain or increase their grain yield potential. In this study, we evaluated the effect of different seed treatment products, such as micronutrients, polymer, fungicide, and insecticide on the yield components and grain yield of wheat. Wheat seeds of the cultivar "Tec Vigore" were subjected to 12 treatments, in different combinations, using the following protective seed products: micronutrient 1 ( $1 \% \mathrm{Mn}, 0.1 \%$ Mo, $10 \% \mathrm{Zn})$, micronutrient $2\left(0.3 \%\right.$ B, $0.3 \%$ Co, 3\% Zn), polymer (ColorSeed $\left.\mathrm{HE}^{\circledR}\right)$, fungicide (Vitavax ${ }^{\circledR}-\mathrm{Thiram}^{-}$ 200 SC), and insecticide (Cruiser ${ }^{\circledR} 350$ FS). At the point of physiological maturity, we proceeded with the following evaluations of the wheat crop: the number of tillers per plant, the number of fertile tillers per plant, grains per ear, the mass of grains per ear, and grain yield. Seed treatment did not affect the number of grains per ear or the mass of grains per ear. The number of tillers per plant and the number of fertile tillers per plant were higher in seeds treated with fungicide + insecticide; however, seed treatment did not significantly affect wheat grain yield.
\end{abstract}

Keywords: Ears. Grain yield. Tillers. Triticum aestivum L..

\section{O tratamento de sementes afeta os componentes de rendimento do trigo?}

\begin{abstract}
Resumo
Uma variedade de produtos vem sendo utilizada no tratamento de sementes para manter ou aumentar o potencial produtivo de grãos. Neste estudo, avaliou-se o efeito de diferentes produtos aplicados no tratamento de sementes, como micronutrientes, polímero, fungicida e inseticida sobre os componentes do rendimento e a produtividade do trigo. Sementes de trigo da cultivar Tec Vigore foram submetidas a doze tratamentos, em diferentes combinações, utilizando os seguintes produtos protetores de sementes: micronutriente 1 ( $1 \% \mathrm{Mn}, 0,1 \% \mathrm{Mo}, 10 \% \mathrm{Zn}$ ), micronutriente $2\left(0,3 \%\right.$ B, 0,3\% Co; $3 \% \mathrm{Zn}$ ), polímero (ColorSeed $\left.\mathrm{HE}^{\circledR}\right)$, fungicida (Vitavax ${ }^{\circledR}$-Thiram $200 \mathrm{SC}$ ) e inseticida (Cruiser ${ }^{\circledR} 350$ FS). Na maturação fisiológica do trigo, procedemos as seguintes avaliações: número de perfilhos por planta, número de perfilhos férteis por planta, grãos por espiga, massa de grãos por espiga e produtividade de grãos. $\mathrm{O}$ tratamento de sementes não afetou o número de grãos por espiga nem a massa de grãos por espiga. $\mathrm{O}$ número de perfilhos por planta e o número de perfilhos férteis por planta foram superiores em sementes tratadas com fungicida + inseticida, entretanto o tratamento de sementes não afetou significativamente a produtividade de grãos de trigo.
\end{abstract}

Palavras-chave: Espigas. Perfilhos. Produção de grãos. Triticum aestivum L..

${ }^{1}$ Universidade Federal de Santa Maria. Santa Maria, RS. Brasil. https://orcid.org/0000-0001-9086-9882

${ }^{2}$ Instituto Federal de Educação, Ciência e Tecnologia do Rio Grande do Sul. Ibirubá, RS. Brasil. https://orcid.org/0000-0002-1350-0181

${ }^{3}$ Instituto Federal de Educação, Ciência e Tecnologia do Rio Grande do Sul. Bento Gonçalves, RS. Brasil. https://orcid.org/0000-0002-5389-5325

*Autor para correspondência: jaf.freiberg@gmail.com

Recebido para publicação em 25 de fevereiro de 2021. Aceito para publicação em 01 de abril de 2021 e-ISSN: 2447-6218 / ISSN: 2447-6218. Atribuição CC BY. 


\section{Introduction}

Seed treatment promotes the protection of seeds and seedlings against diseases transmitted by seeds and insect pests, which affect the emergence of seedlings, their growth, and the grain yield potential. Based on the importance of seed treatments, there have been studies reporting their effect on the initial performance.

In initial seedling establishment, seed treatment can compensate for systems with smaller plant establishments (Beres et al., 2016), especially those from low vigor seeds (Heer, 1998). However, only a few studies have reported the effect of seed treatment on the grain yield of the cultures, notably in cultures such as wheat.

Considering grain yield, Freiberg et al. (2017) found that seed treatment, which included the polymer + micronutrient treatment (1\% Mn, 0.1\% Mo, 10\% Zn), had a negative effect on wheat grain yield and reduced hectoliter weight. Conversely, Rufino et al. (2013) reported an increase in the grain mass per plant after the seed treatment with $\mathrm{Zn}$. Meanwhile, the use of fungicide, $\mathrm{Zn}$, and polymer, either alone or in combination, did not show a significant effect on the hectoliter weight of wheat.

The purpose of this study was to evaluate the effect of different products used in seed treatments, such as micronutrients, polymer, fungicide, and insecticide, on the yield components and on the grain yield of wheat.

\section{Material and methods}

The experiment was carried out on crops grown during 2013 in the experimental area of the Instituto Federal de Educação, Ciência e Tecnologia do Rio Grande do Sul, Campus Ibirubá, RS, Brazil. Wheat seeds of the cultivar "Tec Vigore" that were used in the sowing were produced in the 2012 crop. These seeds belonged to the same genetic category, and presented an $80 \%$ germination rate and had $93 \%$ purity. Wheat seeds were subjected to 12 treatments, in different combinations, using the following protective seed products: micronutrient 1 ( $1 \% \mathrm{Mn}$, $0.1 \%$ Mo, $10 \% \mathrm{Zn})$, micronutrient 2 (0.3\% B, 0.3\% Co, $3 \% \mathrm{Zn}$ ), polymer (ColorSeed $\mathrm{HE}^{\circledR}$ ), fungicide (Vitavax ${ }^{\circledR}$ Thiram 200 SC), and insecticide (Cruiser ${ }^{\circledR} 350$ FS). Doses of $1.5 \mathrm{~mL} \mathrm{.} \mathrm{kg}{ }^{-1} ; 1.2 \mathrm{~mL} \mathrm{~kg}^{-1} ; 2.5 \mathrm{~mL} \mathrm{~kg}^{-1}$; and $1.0 \mathrm{~mL} \mathrm{~kg}{ }^{-1}$ were used in the treatments of micronutrients, polymer, fungicide, and insecticide, respectively. The mixture of products and water was prepared in plastic bags with a capacity of $2 \mathrm{~kg}$. Thereafter, $0.5 \mathrm{~kg}$ of wheat seeds were packaged and shaken until completely coated. The experiment was carried out in randomized blocks, with twelve treatments and four replications per treatment, totaling 48 experimental units.
The experiment was implemented in June 2013, through direct sowing, after the soybean culture. The plots consisted of 20 rows that were five meters in length and spaced at 0.17 meters. The crop management followed the recommendations of the Comissão de Química e Fertilidade do Solo - RS/SC [Commission of Chemistry and Soil Fertility - RS/SC] (2004) and the technical information for the control of weeds, diseases, and pests in wheat crops 2013 (IAPAR, 2012). At the point of physiological maturity, we proceeded with the following evaluations of the wheat crop: the number of tillers per plant, determined by counting the tillers of each plant in $0.5 \mathrm{~m}$; the number of fertile tillers per plant, by counting the tillers with at least one grain; grains per ear, by counting the number of grains of seven ears collected randomly in each plot; and the mass of grain per ear by determining the mass of grains in each ear. Furthermore, we evaluated the grain yield by harvesting 6 central rows measuring 3 meters in each plot. The grain mass was weighted, then the value was adjusted to $13 \%$ humidity and expressed in $\mathrm{kg} \mathrm{ha}^{-1}$.

The data were analyzed considering twelve treatments and four repetitions in a randomized block design. The analysis of variance and test of hypotheses were performed to verify the effect of the treatments, and logarithmic transformations of data (log10) were applied when the normality of data was violated. When significant, the means were compared using the Scott-Knott test at a 5\% probability level in the package 'easyanova' (Arnhold, 2013). Yield component values were also correlated with the grain yield using Pearson's correlation at a 5\% probability level. All analyses were performed on R (R Core Team 2019).

\section{Results and discussion}

Seed treatment did not affect the number of grain per ear or the mass of grain per ear (Figure 1, Table 1). However, a significant effect of seed treatment was observed on the number of tillers per plant and the number of fertile tillers per plant (Figure 1, Table 1). For the control treatment (C), and the fungicide and insecticide (FI), the number of tillers was $60 \%$ and $99 \%$ higher than the average of other seed treatments.

The number of tillers is an important variable associated with grain yield, especially when tillers provide ears (Camponogara et al., 2016). We observed a positive effect from using fungicide and insecticide (FI), as well as with the micronutrients treatments (M1 and M2), on the number of fertile tillers. However, this effect did not differ significantly from the control. Conversely, the lowest number of fertile tillers was obtained when the fungicide and insecticide were mixed with the polymer. 
Does seed treatment affect wheat yield components?

Table 1 - Summary of the analysis of variance ( $p$ value and coefficient of variation \%) and Pearson correlation.

\begin{tabular}{lcccc}
\hline Analysis of variance & \multicolumn{3}{c}{ Pearson correlation* } \\
\hline Variable & $\boldsymbol{p}$ value & CV (\%) & Correlation & $\boldsymbol{p}$ value \\
\hline Grains per ear & 0.7557 & 7.95 & -0.1665 & 0.2581 \\
Mass of grains per ear & 0.3796 & 8.82 & -0.1175 & 0.1175 \\
Number of tillers per plant & 0.0049 & 33.14 & 0.0942 & 0.5244 \\
Number of fertile tillers per plant & 0.0099 & 38.42 & 0.1262 & 0.3928 \\
Grain yield & 0.8636 & 10.65 & - & - \\
\hline
\end{tabular}

*Coefficients referrer to the association between grain yield and the respective yield component.

Furthermore, the quantitative variables of yield components did not show a significant association with the grain yield (Table 1) and no significant effect of seed treatment was observed on grain yield (Figure 2). According to Vesohoski et al. (2011), the length of the ear, number of spikelets per ear, and the number of grains per ear have a positive association with grain yield. Even though we have not found a significant correlation between the number of tillers and grain yield, Valério et al. (2013) pointed out that the genotype significantly affects the production of tillers and noted that expression of this characteristic depends on the sowing density. In this sense, genotypes with high tillering potential should adopt a lower plant density per meter to obtain greater grain yield. Among the important characteristics to consider when selecting wheat genotypes in Brazil, Vesohoski et al. (2011) reported that the weight of a thousand grains is associated with the number of grains per ear. In addition, Desheva and Kachakova et al. (2013) reported that the length of the ear, grains per ear, and the grain mass per ear are also relevant, as well as the number of ears per unit area (Zhou et al. 2018).

Regarding the seed treatment, a few studies have reported its effects on wheat yield components. Rufino et al. (2013) observed an increase in grain mass per plant after seed treatment with Zn. Additionally, while they found that Zn significantly affected the yield, no significant effect on the hectoliter weight of the wheat was observed after the seed treatment with fungicide, zinc (Zn), and polymer, alone or in combination (Rufino et al., 2013). Meanwhile, the control seeds produced the lowest mass per plant, but this group had the highest hectoliter weight. Furthermore, Freiberg et al. (2017) did not report a significant and positive effect of seed treatment on grain yield after treatments with micronutrients, polymer, fungicide, and insecticide, whether isolated or in combinations. Conversely, Turkington et al. (2016) reported that the combination of fungicide and insecticide provided the highest yield and economic return. These contrasting responses might have been due to the protective products used on seed treatment, the cultivars, and the environmental and management conditions of the different stages of the phenological development of wheat crops.

From a critical viewpoint, Pedrini et al. (2016) question the use of products in seed treatment, especially the polymers used in the coating. Although the coating is perceived as a high-tech method that provides modifications to facilitate the handling of seeds and the addition of other products, these authors highlight the need for research to substantiate these uses and question whether the amount of material used in coating is necessary. In this sense, more studies testing different protective products and their combinations should be carried out to elucidate the influence of seed treatment on the yield components of wheat, as well as on grain yield.

\section{Conclusions}

Seed treatment with micronutrients, polymer, fungicide, and insecticide, whether separately or in combinations, does not affect the number of grains per ear or the mass of grain per ear. However, the number of tillers and fertile tillers may increase after the seed treatment with fungicide and insecticide without influencing the grain yield of wheat.

\section{Acknowledgments}

We would like to thank the Fundação de Amparo à Pesquisa do Estado do Rio Grande do Sul [Foundation for Research Support of the State of Rio Grande do Sul] FAPERGS, for the scholarship granted to the first author. We would also like to express gratitude to the members of the Laboratório de Sementes e Grãos of the Instituto Federal de Educação, Ciência e Tecnologia do Rio Grande do Sul - Campus Ibirubá, for their assistance in the field and laboratory, and also to the mother of the first author for assisting with the analysis of the yield components. 
Figure 1 - Yield components of wheat seed subjected, or not, to seed treatment with M1-Micronutrient 1 (1\% Mn; 0.1\% Mo; 10\% Zn), M2-Micronutrient 2 (0.3\% B; 3\% Co; Zn 3\%), P $\neg$-polymer, and Fungicide (F) + Insecticide (I). C-control.
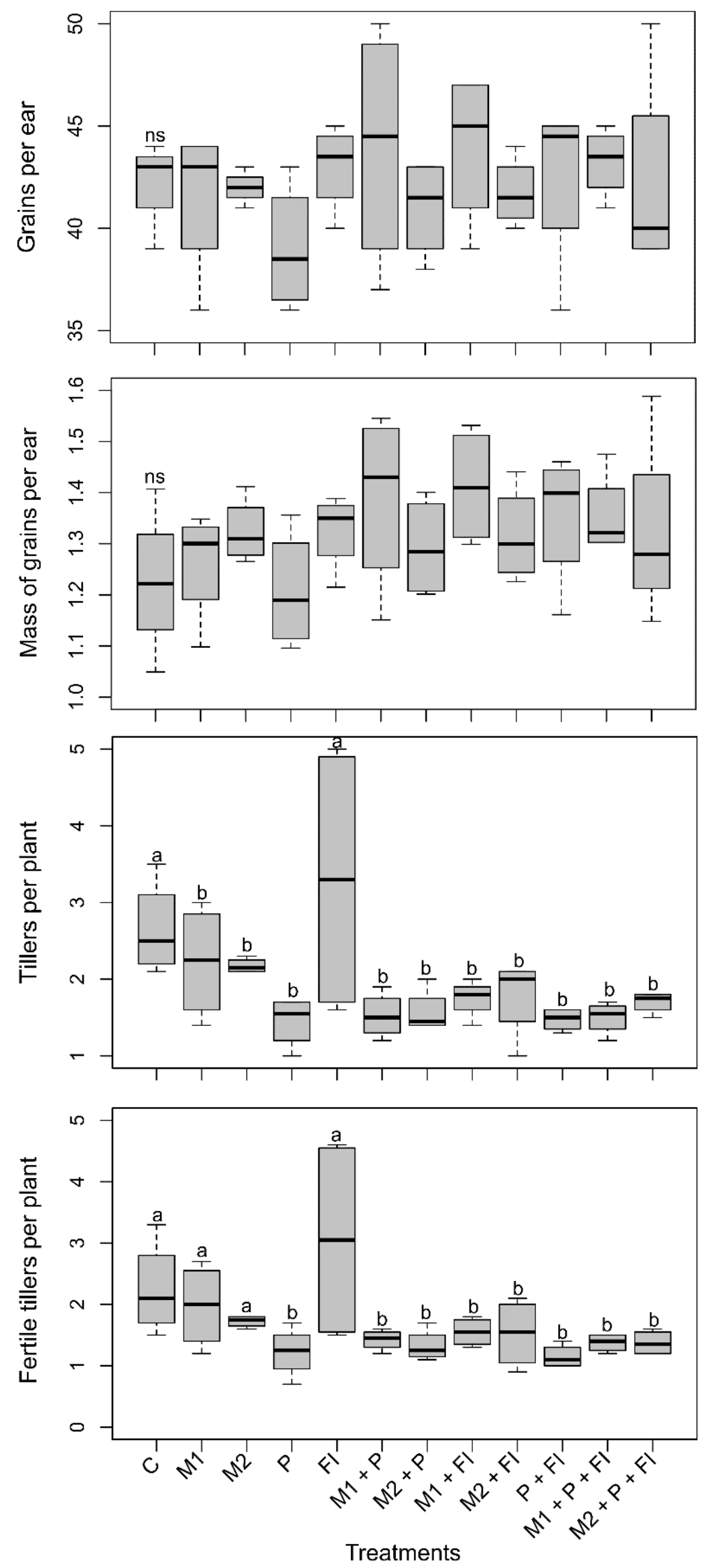

Cad. Ciênc. Agrá., v. 13, p. 01-05, https://doi.org/10.35699/2447-6218.2021.29642 
Figure 2 - Grain yield (kg ha-1) of wheat subjected, or not, to seed treatment with M1-Micronutrient 1 (1\% Mn; $0.1 \%$ Mo; 10\% Zn), M2-Micronutrient 2 (0.3\% B; 3\% Co; Zn 3\%), P ᄀ-polymer, and Fungicide (F) + Insecticide (I). C-control.

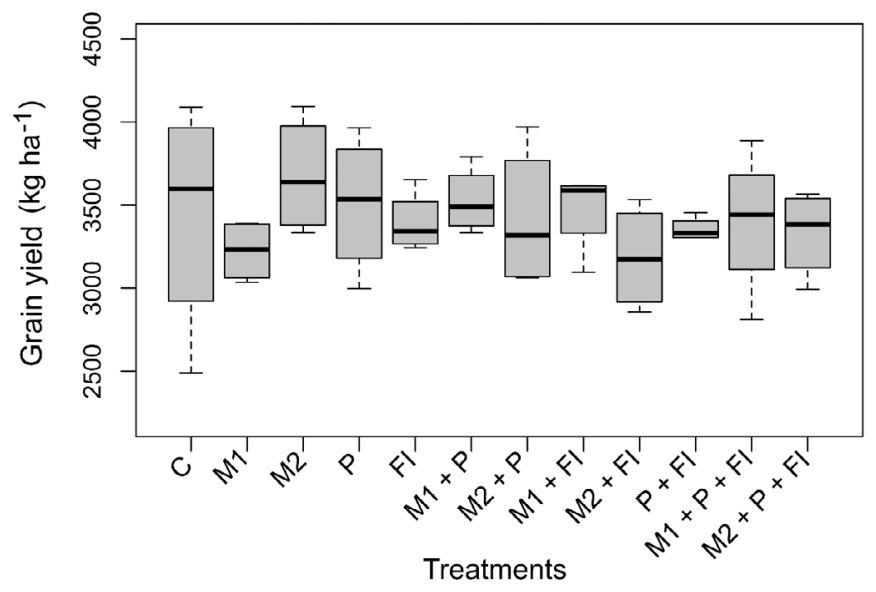

\section{References}

Arnhold, E. 2013. Package in the R environment for analysis of variance and complementary analyses. Brazilian Journal of Veterinary Research and Animal Science, 50: 488-492. Doi: https://doi.org/10.11606/ issn.1678-4456.v50i6p488-492.

Beres, B. L.; Turkington, T. K.; Kutcher, H. R.; Irvine, B.; Johnson, E. N.; O’Donovan, J. T.; Harker, K. N.; Holzapfel, C. B.; Mohr, R.; Peng, G.; Spaner, D. M. 2016. Winter Wheat Cropping System Response to Seed Treatments, Seed Size, and Sowing Density. Agronomy Journal, 108: 1101-1111. Doi: https://doi.org/10.2134/agronj2015.0497.

Comissão de Química e Fertilidade do Solo RS/SC - CQFS-RS/SC. 2004. Manual de adubação e de calagem para o Estado do Rio Grande do Sul e Santa Catarina. Porto Alegre: UFRGS, 400p.

Camponogara, A. S.; Oliveira, G. A.; Georgin, J.; Rosa, A. L. D. 2016. Avaliação dos componentes de rendimento do trigo quando submetido a diferentes fontes de nitrogênio. Revista Eletrônica em Gestão, Educação e Tecnologia Ambiental, 20: 524-532. Doi: https://doi. org/105902/2236117019723.

Descheva, G.; Kachakova, S. 2013. Correlations between the main structural elements of yield in common wheat cultivars. Plant Science, 50: 5-8.

Freiberg, J. A.; Ludwig, M. P.; Avelar, S. A. G.; Girotto, E. 2017. Seed treatment and its impact on wheat crop yield potential. Journal of Seed Science, 39: 280-287. Doi: https://doi.org/10.1590/2317$1545 \mathrm{v} 39 \mathrm{n} 3177754$.

Heer, W. F. 1998. Wheat emergence and yield as related to cultivar and seed treatment. Transactions of the Kansas Academy of Science, 101: 82-88. Doi: https://doi.org/10.2307/3627954.

IAPAR. Instituto Agronômico do Paraná. 2012. Informações técnicas para trigo e triticale safra 2013. In: VI Reunião da Comissão Brasileira de Pesquisa de Trigo e Triticale. Londrina,PR: Instituto Agronômico do Paraná, 220p. Doi: http://www.iapar.br/arquivos/File/zip_pdf/ TrigoeTriticale 2013.pdf.
Pedrini, S.; Merritt, D. J.; Stevens, J.; Dixon, K. 2016. Seed coating: science or marketing spin? Trends in Plant Science, 22: 106-116. Doi: https://doi.org/10.1016/j.tplants.2016.11.002.

R Core Team. 2019. R: A language and environment for statistical computing. R Foundation for Statistical Computing, Vienna, Austria. Available on: https://www.R-project.org/.

Rufino, C. A.; Tavares, L. C.; Brunes, A. P.; Lemes, E. S.; Villela, F. A. 2013. Treatment of wheat seed with zinc, fungicide, and polymer: seed quality and yield. Journal of Seed Science, 35: 106-112. Doi: https:// dx.doi.org/10.1590/S2317-15372013000100015.

Valério, I. P.; Carvalho, F. I. F.; Benin, G.; Silveira, G.; Silva, J. A. G.; Nornberg, R.; Hagemann, T.; Luche, H. S.; Oliveira, A. C. 2013. Seeding density in wheat: the more, the merrier? Scientia Agricola. 70: 176184. Doi: http://dx.doi.org/10.1590/S0103-90162013000300006.

Turkington, T. K.; Beres, B. L.; Kutcher, R. H.; Irvine, B.; Johnson, E. N.; O'Donovan, J. T.; Harker, K. N.; Holzapfel, C. B.; Mohr, R.; Peng, G.; Stevenson, F. C. 2016. Winter wheat yields are increased by seed treatment and fall-applied fungicide. Agronomy Journal, 108: 13791389 Doi: https://doi.org/10.2134/agronj2015.0573.

Vesohoski, F.; Marchioro, V. S.; Franco, F. A.; Cantelle A. 2011. Componentes do rendimento de grãos em trigo e seus efeitos diretos e indiretos na produtividade. Revista Ceres, 58: 337-341. https://doi. org/10.1590/S0034-737X2011000300014.

Zhou, C.; Liang, D.; Yang, X.; Yang, H.; Yue, J.; Yang, G. 2018. Wheat ears counting in field conditions based on multi-feature optimization and TWSVM. Frontiers in Plant Science, 9: 1024. Doi: https://doi. org/10.3389/fpls.2018.01024. 